\title{
HEPATOSOMATIK INDEKS DAN DIAMETER HEPATOSIT MENCIT (Mus musculus L.) BETINA SETELAH PAPARAN EKSTRAK ETANOL DAUN MIMBA (Azadirachta indica Juss.)
}

\author{
Anisa Nurul Hasana ${ }^{1}$, Agung Janika Sitasiwi², Sri Isdadiyanto ${ }^{3}$ \\ ${ }^{1,2,3}$ Departement of Biology, Science and Mathematics Faculty, Diponegoro University, Semarang \\ Corresponding author: agssiwi@yahoo.co.id
}

\begin{abstract}
Neem leaves is one part of the neem tree which can be used as a traditional medicinal herb. The purpose of this study was to examine the effect of neem leaf ethanol extract on hepatosomatic index (HSI) and hepatocyte diameter in female mice. The study used a Complete Randomized Design consist of 4 treatments and 5 replications including $K$ (aquadest), P1, P2 and P3 (neem leaf ethanol extract with dose of 8.4,11.2 and $14 \mathrm{mg} /$ $\mathrm{kg} \mathrm{BW/day.} \mathrm{The} \mathrm{treatment} \mathrm{was} \mathrm{administered} \mathrm{orally} \mathrm{with} \mathrm{a} \mathrm{volume} \mathrm{of} 0.2 \mathrm{~mL}$ for 21 days. Body weight were measured every 7 days. The liver was isolated, weighed and histologically prepared with paraffin method, HE staining and $5 \mu \mathrm{m}$ incision thickness. HSI value determined from body weight and liver weight. Hepatocyte diameter were measured on 7 hepatocytes per lobule. The data was analyzed using ANOVA at 95\% confidence level. The results showed that neem leaf ethanol extract had no significant effect $(p>0,05)$ on body weight, liver weight, HSI value and hepatocyte diameter, but the liver microanatomy showed hepatocyte damage. It can be concluded that exposure of neem leaf ethanol extract for 21 days still safe to be used for reference of traditional medicine.
\end{abstract}

Keywords: Neem leaf, HSI, hepatocyte diameter

\section{PENDAHULUAN}

Obat tradisional merupakan bahan atau ramuan bahan yang berasal dari tumbuhan, hewan, mineral, sediaan sarian (galenik), atau campuran dari bahan tersebut yang secara turun temurun telah digunakan untuk pengobatan dan dapat diterapkan sesuai dengan kebiasaan yang telah berjalan di masyarakat. Mimba (Azadirachta indica Juss.) merupakan salah satu tanaman yang dimanfaatkan sebagai obat tradisional (Kepmenkes RI, 2017).

Obat tradisional dari bahan tanaman akan melalui proses pencernaan di dalam saluran pencernaan, untuk selanjutnya diserap oleh intestinum dan didetoksifikasi di dalam hepar. Oleh karena itu, hepar sangat rentan terhadap pengaruh berbagai zat kimia yang masuk ke dalam tubuh melalui saluran pencernaan dan sering menjadi sasaran utama dari efek racun zat kimia (Kurniawan et al., 2014).

Hepar memiliki keterkaitan dengan bobot tubuh karena hepar melakukan metabolisme zat makanan yang nantinya digunakan untuk aktivitas fisik ataupun disimpan sebagai cadangan makanan dalam tubuh. Zat makanan yang disimpan dalam tubuh akan mempengaruhi bobot badan dari suatu individu (Niendya et al., 2011). Bobot badan dan bobot hepar digunakan untuk menentukan nilai indeks hepatosomatik, berkaitan dengan fungsi hepar sebagai cadangan energi dan aktivitas metabolik (Ashwini et al., 2016).

Perubahan morfologi dan fisiologi sel hepar yang mengalami cedera diawali dengan peningkatan penyerapan air, 
kemudian menyebar hingga organel dan sitoplasma. Hal tersebut menyebabkan pembengkakan sel, dicirikan dengan peningkatan volume dan ukuran sel (Zachary and McGavin, 2012). Peningkatan ukuran sel ditandai dengan perubahan diameter sel hepatosit.

$$
\text { Ervina dan Sukarjati }
$$

menyatakan bahwa pemberian ekstrak etanol daun mimba dosis $50 \mathrm{mg} / \mathrm{kg} \mathrm{BB}$ pada mencit (Mus musculus L.) jantan berpengaruh terhadap kerusakan histologi hepar mencit, yaitu degenerasi dan peningkatan menjadi kongesti, hemoragi, edema, dan radang.

Kerusakan sel hepar dimulai dengan proses degenerasi yaitu pembengkakan sel. Pembengkakan sel bersifat reversible, sehingga dapat kembali seperti semula. Tahap kerusakan sel hepar selanjutnya yaitu nekrosis, merupakan kerusakan yang bersifat irreversible. Tahap akhir kerusakan hepar adalah nekrosis, yaitu sel akan mengalami kematian (Maulida et al., 2013).

Berdasarkan latar belakang maka dilakukan penelitian mengenai pengaruh ekstrak etanol daun mimba (Azadirachta indica Juss) terhadap nilai HSI dan diameter hepatosit. Tujuan dari penelitian ini yaitu menguji pengaruh pemberian ekstrak etanol daun mimba (Azadirachta indica Juss.) terhadap hepatosomatik indeks dan diameter hepatosit pada mencit (Mus musculus L.) betina. Penelitian ini diharapkan dapat memberikan informasi tentang pengaruh ekstrak etanol daun mimba terhadap organ hepar mencit betina, khususnya mengenai hepatosomatik indeks dan diameter hepatosit, sehingga dapat digunakan sebagai bahan rujukan tingkat keamanan penggunaan ekstrak etanol daun mimba (Azadirachta indica Juss.) sebagai obat tradisional.

\section{METODE PENELITIAN}

Penelitian ini dilaksanakan selama 2,5 bulan di Lab. BSF Hewan, Universitas Diponegoro, Semarang.

\section{Persiapan Hewan Uji}

Hewan uji yang digunakan yaitu mencit betina galur Swiss Webster berumur 2,5 bulan dengan kisaran bobot 20-29 g dan tanpa cacat anatomis. Hewan diaklimatisasi pada kondisi laboratorium yang terkontrol selama seminggu. Mencit dipelihara pada kandang berukuran 20x30cm yang dilengkapi dengan penutup kawat, tempat pakan, tempat minum dan sekam padi serta kepadatan hewan \pm 3 ekor per kandang. Pakan standar HI-PRO-VITE Medicated 594 dan air minum diberikan secara ad libitum.

\section{Ekstraksi Daun Mimba}

Sampel daun mimba diperoleh dari area kampus Fakultas Sains dan Matematika, Universitas Diponegoro. Daun dikeringkan dalam oven dengan suhu 45$50^{\circ} \mathrm{C}$. Susunan daun dibalik setiap hari hingga kering secara merata. Depkes RI 
Hasana Anisa Nurul, dkk. Hepatosomatik Indeks dan Diameter Hepatosit Mencit (Mus musculus L.) Betina Setelah Paparan Ekstrak Etanol Daun Mimba (Azadirachta indica Juss.)

(2008) menjelaskan bahwa daun dinyatakan kering jika berat mencapai konstan dengan syarat menimbang 2 kali penimbangan secara berturut-turut. Daun yang telah kering dihancurkan secara mekanik menggunakan tangan hingga terbentuk serbuk. Ekstraksi daun mimba dilakukan di Laboratorium Kimia Universitas Negeri Semarang dengan metode maserasi menggunakan etanol 70\%, dievaporasi sampai ekstrak berbentuk serbuk.

\section{Persiapan Bahan Uji}

Acuan penentuan dosis didasarkan pada penelitian Ashafa et al. (2012) yang menguji ekstrak etanol kulit batang mimba (Azadirachta indica) pada tikus jantan Wistar dari kisaran dosis 50-300 mg/kg BB. Berdasarkan Laurence and Bacharach (1964) menyatakan konversi dosis dari tikus ke mencit sebesar 0,14, sehingga dosis untuk mencit yang didapat yaitu 8,4 $\mathrm{mg} / \mathrm{kgBB} ; 11,2 \mathrm{mg} / \mathrm{kgBB}$ dan $14 \mathrm{mg} / \mathrm{kgBB}$. Pembuatan larutan stok sebanyak 0,168 mg; 0,224 mg dan 0,28 mg ekstrak etanol daun mimba masing-masing dilarutkan dalam 10 $\mathrm{mL}$ air hangat.

\section{Pemberian Perlakuan dan Pengamatan}

Rancangan penelitian menggunakan rancangan acak lengkap (RAL) yang terdiri dari 4 perlakuan yaitu $\mathrm{K}$ (bahan uji akuades), P1, P2 dan P3 (ekstrak etanol daun mimba dosis 8,4; 11,2 dan $14 \mathrm{mg} / \mathrm{kg}$ $\mathrm{BB} /$ hari), masing-masing dengan 5 ulangan. Pemberian bahan uji dilakukan dengan cara gavage, volume 0,2 mL/ekor selama 21 hari. Pengamatan yang dilakukan selama penelitian meliputi pengamatan konsumsi minum setiap hari, konsumsi pakan setiap 3 hari dan bobot badan setiap minggu. Isolasi organ hepar dilakukan setelah perlakuan berakhir, organ ditimbang dan selanjutnya dibuat preparat histologis dengan metode paraffin, pewarnaan hematoksilin-eosin dan tebal sayatan $5 \mu \mathrm{m}$. Pengukuran diameter hepatosit menggunakan fotomikrograf dengan perbesaran 400x. Pengukuran dilakukan pada 7 hepatosit setiap lobulus, 5 lobulus diamati setiap sayatan organ dan setiap preparat organ diwakili 3 sayatan organ. Nilai HSI dihitung sesuai rumus menurut Ogunji et al. (2008) sebagai berikut.

$$
\mathrm{HSI}=\frac{\mathrm{BH}}{\mathrm{BB}} \times 100
$$

Keterangan:

HSI $=$ hepatosomatik indeks $(\%)$

$\mathrm{BH}=$ bobot hepar $(\mathrm{g})$

$\mathrm{BB}=$ bobot badan $(\mathrm{g})$

\section{Analisis Data}

Data berat badan, berat hepar, HIS dan diameter hepatosit dianalisis dengan menggunakan uji ANOVA dengan taraf signifikansi 95\%. Hasil yang menunjukkan beda nyata diuji lebih lanjut menggunakan Duncan Multiple Range Test (DMRT). Analisis data menggunakan program SPSS versi 23.0. 


\section{HASIL DAN PEMBAHASAN}

Berdasarkan hasil ANOVA (Tabel 1) menunjukkan bahan uji memberikan hasil yang berbeda tidak bermakna $(\mathrm{p}>0,05)$ terhadap bobot badan, bobot hepar, indeks hepatosomatik dan diameter hepatosit mencit betina. Rerata bobot badan mencit (Tabel 1) pada semua kelompok perlakuan menunjukkan bahwa pemberian bahan uji ekstrak etanol daun mimba tidak mempengaruhi bobot badan mencit betina. Ashafa et al. (2012) menjelaskan bahwa pemberian ekstrak etanol kulit batang mimba pada dosis $50-100 \mathrm{mg} / \mathrm{kgBB}$ belum dapat memengaruhi bobot tubuh tikus jantan bila dibandingkan kelompok kontrol. Hewan uji betina diduga masih dapat mentolerir paparan senyawa dalam ekstrak etanol daun mimba, sehingga tidak mempengaruhi bobot tubuh.

Hepar merupakan organ target toksisitas, paparan zat toksik dalam tubuh dapat menaikkan ataupun menurunkan bobot hepar (Harbison et al., 2015). Paparan ekstrak etanol daun mimba terhadap bobot hepar menunjukkan hasil yang berbeda tidak bermakna $(p>0,05)$. Hal tersebut diduga karena kandungan senyawa dalam ekstrak etanol daun mimba dapat dimetabolisme dan didetoksifikasi dalam organ hepar.

Bobot hepar hewan uji berkisar antara 1,37-1,51 gram. Bobot hepar tersebut masih dalam kisaran normal. Kurniawan et al.
(2014) menjelaskan bahwa bobot hepar normal mencit dewasa berkisar antara 1,21,6 gram.

Hepar mencit umumnya berwarna merah kecoklatan, sedangkan hepar yang abnormal memiliki warna yang pucat dan permukaan berbintik (Prasetiawan et al., 2012). Abnormalitas hepar yang terpapar zat toksik dapat ditandai dengan perubahan warna hepar menjadi merah kekuningan hingga coklat kekuningan (Tatukude et al., 2014).

Hepar hewan uji (Gambar 1) memiliki warna merah kecoklatan baik kelompok kontrol dan kelompok perlakuan. Hal itu menunjukkan bahwa pemberian ekstrak etanol daun mimba tidak memberikan perbedaan yang bermakna pada warna hepar mencit.

Bobot badan dan bobot hepar mencit digunakan untuk menentukan nilai HSI. Berdasarkan hasil ANOVA (Tabel 1) menunjukkan bahwa pemberian ekstrak etanol daun mimba menunjukkan hasil berbeda tidak bermakna $(p>0,05)$ terhadap nilai HSI mencit betina. Hepatosomatik indeks (HSI) menggambarkan jumlah cadangan energi dalam tubuh serta kondisi hewan (Nunes et al., 2011). Paparan ekstrak etanol daun mimba diduga belum menyebabkan gangguan pada metabolisme nutrisi sehingga nilai HSI menunjukkan hasil berbeda tidak bermakna. 
Hasana Anisa Nurul, dkk. Hepatosomatik Indeks dan Diameter Hepatosit Mencit (Mus musculus L.) Betina Setelah Paparan Ekstrak Etanol Daun Mimba (Azadirachta indica Juss.)

Berdasarkan hasil ANOVA (Tabel 1) menunjukkan bahwa pemberian ekstrak etanol daun mimba menunjukkan hasil berbeda tidak bermakna $(\mathrm{p}>0,05)$ terhadap diameter hepatosit.

Berdasarkan hasil ANOVA (Tabel 1) menunjukkan bahwa paparan ekstrak etanol daun mimba memperlihatkan hasil yang berbeda tidak bermakna terhadap konsumsi pakan dan konsumsi air minum mencit. Hal tersebut sesuai dengan Sitasiwi (2018) yang menjelaskan bahwa pemberian ekstrak etanol daun mimba menunjukkan hasil berbeda tidak bermakna pada konsumsi pakan antara hewan uji kelompok perlakuan dengan kelompok kontrol. Kandungan senyawa nimbidin dalam ekstrak etanol daun mimba bersifat diuretik (Pankaj et al., 2011), namun kandungan senyawa tersebut diduga belum dapatmempengaruhi sistem metabolisme cairan dalam tubuh, sehingga baik kelompok kontrol dan kelompok perlakuan menunjukkan hasil berbeda tidak bermakna.

Senyawa aktif yang terisolasi dalam ekstrak etanol daun mimba antara lain karbohidrat, glikosida, protein, senyawa fenol, tanin, flavonoid dan saponin (Singh and Chauhan, 2014). Senyawa nimbidin daun mimba berperan sebagai agen hipoglikemik (Pankaj et al., 2011), diduga dapat menurunkan ketersediaan energi dalam tubuh hewan uji yang dapat berpengaruh pada nilai HSI.
Azadirachtin merupakan kompleks limonoid tetra-nor-triterpenoid yang memiliki efek antifeedant (Soni et al., 2012). Sa'diyah et al. (2013) menambahkan bahwa fenol merupakan metabolit sekunder yang bersifat anti-feedant. Hal itu akan mempengaruhi tingkat konsumsi pakan mencit.

Senyawa flavonoid pada ekstrak daun mimba dapat menghambat enzim sitokrom P-450, meningkatkan bioavailabilitas zat toksik sehingga menimbulkan efek dari zat toksik dan meningkatkan toksisitasnya dalam tubuh (Budiono, 2000). Inaya et al. (2015) menambahkan bahwa senyawa flavonoid dapat mendenaturasi protein pada membran sel, sehingga membran sel tersebut terganggu permeabilitasnya dan menyebabkan kebocoran sel.

Tanin merupakan metabolit sekunder yang memiliki efek anti mitotik dan bersifat sitotoksik pada sel yang mengalami pembelahan cepat (Setyowati et al., 2015). Kandungan senyawa tanin pada daun mimbadiduga belum dapat mempengaruhi proses regenerasi sel sehingga tidak mempengaruhi bobot badan, bobot hepar dan nilai HSI.

Tanin memiliki efek spasmolitik yang diduga dapat mengerutkan dinding sel atau membran sel sehingga mengganggu permeabilitas membran sel, akibatnya sel tidak dapat melakukan aktivitas hidup sehingga pertumbuhan terhambat atau 
bahkan mati (Ajizah, 2004).Saponin memiliki aktivitas sitotoksik. Paparan saponin melalui per oral akan sedikit yang terserap ke dalam tubuh manusia maupun hewan (Podolak et al., 2010). Kandungankandungan senyawa pada ekstrak etanol daun mimba dapat menyebabkan kerusakan pada sel hepatosit mencit.

Gambaran histologis hepar kelompok kontrol (Gambar 2) menunjukkan adanya sel hepatosit. Hepatosit merupakan sel poligonal dengan membran sel yang jelas. Nukleus pada hepatosit yang berbeda menunjukkan variasi bentuk dan ukuran, pada beberapa kasus merupakan binukleat (Smith and Morton, 2010).

Hepatosit tersusun secara radikal mengelilingi vena sentralis, di mana antar hepatosit dipisahkan oleh sinusoid. Sinusoid memiliki peran penting dalam hepar yakni mewakili sistem pertahanan yang terdiri dari makrofag sel Kupffer (Al-Easawi and Al-Azzawi, 2015).

Gambaran histologis hepar kelompok perlakuan P1 (Gambar 3) menunjukkan adanya kerusakan hepatosit yaitu degenerasi hidrofik. Degenerasi hidropik merupakan tingkat kerusakan struktur hepatosit yang ditandai dengan sitoplasma mengalami vakuolisasi, vakuola-vakuola nampak jernih dan terjadi karena peningkatan pemasukan air ke dalamsel dan kemudian air memasuki vakuola-vakuola tersebut (Hastuti, 2006).
Gambaran histologis hepar kelompok P2 (Gambar 4) menunjukkan adanya kerusakan sel yaitu kongesti, degenerasi hidrofik, degenerasi lemak dan nekrosis. Degenerasi lemak ditandai dengan sitoplasma hepatosit terbentuk satu vakuola besar yang berisi lemak, sehingga nukleus terdesak ke tepi sel (Hastuti, 2006). Akumulasi lemak di dalam sel hepar dapat disebabkan radikal bebas (Tatukude et al., 2014).

Gambaran histologis hepar kelompok P3 (Gambar 5) menunjukkan adanya kerusakan seperti degenerasi hidrofik, degenerasi lemak dan nekrosis. Nekrosis ditandai dengan ciri-ciri yakni nukleus mengkerut (piknosis), nukleus pecah menjadi fragmen-fragmen (kariokinesis), nukleus lisis (kariolisis) dan membran sel mengalami lisis sehingga batas antar sel tidak nampak jelas (Hastuti, 2006).

Hepar memiliki daya regenerasi yang cepat, proliferasi hepatosit dapat ditandai dengan mitosis dan adanya sel binukleat (Herrington, 2014). Regenerasi hepar juga diperlukan untuk menggantikan hilangnya jaringan di dalam organ (Michalopoulos, 2013). Proses regenerasi tergantung pada antioksidan, mediator proliferasi dan aktivator siklus sel. Ekstrak daun mimba memiliki kapasitas antioksidan yang tinggi, senyawa tersebut meliputi tanin, flavonoid, polifenol dan betakaroten (Suhendro et al., 2018). 
Hasana Anisa Nurul, dkk. Hepatosomatik Indeks dan Diameter Hepatosit Mencit (Mus musculus L.) Betina Setelah Paparan Ekstrak Etanol Daun Mimba (Azadirachta indica Juss.)

Kerusakan hepar akibat zat toksik dapat dipengaruhi oleh beberapa faktor antara lain jenis zat yang terlibat, besarnya dosis yang diberikan dan lamanya paparan zat (Handani et al., 2017). Kerusakan sel dalam penelitian ini diduga bersifat reversible. Hal itu ditunjukkan dengan bobot badan, bobot hepar, nilai HSI dan diameter hepatosit yang berbeda tidak bermakna. Baroroh dan Warsinah (2009) menjelaskan bahwa kerusakan yang bersifat reversible dapat kembali seperti semula apabila rangsangan yang menyebabkan kerusakan dihentikan.

\section{KESIMPULAN}

Paparan ekstrak etanol daun mimba hingga dosis $14 \mathrm{mg} / \mathrm{kg}$ BB selama 21 hari menunjukkan hasil berbeda tidak bermakna terhadap nilai HSI dan diameter hepatosit pada semua kelompok perlakuan. Struktur mikroanatomi menunjukkan gangguan yang bersifat reversible. Sehingga dapat disimpulkan bahwa pemberian ekstrak etanol daun mimba tergolong aman untuk digunakan sebagai obat tradisional.

\section{UCAPAN TERIMA KASIH}

Penelitian ini didanai oleh Fakultas Sains dan Matematika Universitas Diponegoro melalui No.042.01.2.400898/2016 DIPA Research Grant pada tahun 2016.

\section{DAFTAR PUSTAKA}

Ajizah A. 2004. Sensitivitas Salmonella typhimurium terhadap ekstrak daun Psidium guajava L. Bioscientiae, 1(1): 31-38.

Al-Easawi AF and MNA Al-Azzawi. 2015. Histological study in liver of albino mice post exposing to shisha smoke. World Journal of Experimental Biosciences, 3(1): 30-35.

Ashafa AOT, LO Orekoya, and MT Yakubu. 2012. Toxicity profile of ethanolic extract of Azadirachta indica Stem Bark in male wistar rats. Asian Pacific Journal of Tropical Biomedicine 2(10): 811-817.

Ashwini L, S Benakappa, HN Anjanayappa, and Akshay L. 2016. Observation on the Gonado-Somatic Index-GSI and Hepato-Somatic Index-HSI of Decapterus russelli Mangaluru Coast. International Journal of Engineering Science and Computing 6(6) : 73967399.
Baroroh HN dan Warsinah. 2009. Antiinflamatory activity of ethanolic extract of leaves of jarak pagar (Jatropa curcas L.) and neutrophils profile in rats foot induced carrageenan. Proceedings of International Conference On Medicinal Plants, 22-23.

Budiono B dan Herwiyati S. 2000. The histological structure of liver of rats after comsuming extract of lantoro leaf and green tea (Leucaena leucochepala). Jurnal Kedokteran YARSI. 8(2): $16-24$.

Departemen Kesehatan RI. 2008. Farmakope herbal Indonesia edisi I. Jakarta: Depkes RI.

Ervina L dan Sukarjati. 2017. Pengaruh pemberian ekstrak biji pepaya (Carica papaya L.), ekstrak daun mimba (Azadirachta indica A. Juss) serta campuran ekstrak biji pepaya dan ekstrak daun mimba terhadap gambaran histologi ginjal dan hati 
mencit jantan (Mus musculus L.). Wahana 68(1): 61-67.

Handani KS, WS Utami, B Hermansyah, dan R Normasari. 2017. Gambaran histopatologi hati tikus wistar pasca pemberian ekstrak etanol rimpang bangle (Zingiber cassumunar Roxb) pada uji toksisitas akut. Journal of Agromedicine and Medical Sciences, 4(1): 55-59.

Harbison RD, MM Bourgeois, and GT Johnson. 2015. Hamilton \& Hardy's Industrial Toxicology. New Jersey: John Wiley \& Sons Inc.

Hastuti US. 2006. Pengaruh berbagai dosis citrinin terhadap kerusakan struktur hepatosit mencit (Mus musculus) pada tiga zona lobulus hepar. Jurnal Kedokteran Brawijaya, 22(3): 121 126.

Herrington CS. 2014. Muir's textbook of pathology. Boca Raton: CRC Press.

Inaya AFN, Kismiyati, dan S Subekti. 2015. Pengaruh perasan biji pepaya (Carica papaya) terhadap kerusakan telur Argulus japonicus. Jurnal Ilmiah Perikanan dan Kelautan, 7(2): 159164.

Keputusan Menteri Kesehatan RI No.HK.01.07/ Menkes/ 187/ 2017. Formularium ramuan obat tradisional Indonesia.

Kurniawan IWAY, NI Wiratmini, dan NW Sudatri. 2014. Histologi hati mencit (Mus musculus L.) yang diberi ekstrak daun Lamtoro (Leucaena leucocephala). Jurnal Simbiosis II (2): 226-235.

Laurence DR and AL Bacharach. 1964. Evaluation of drug activities: pharmacometrics. London: Academic Press.

Maulida A, Syafruddin I, dan Salomo H. 2013. Pengaruh pemberian vitamin $C$ dan E terhadap gambaran histologis hepar mencit (Mus musculus L.) yang dipajankan Monosodium Glutamat (MSG). Fakultas MIPA, Universitas Sumatera Utara (USU).
Michalopoulus GK. 2013.Principles of liver regeneration and growth homeostasis. Compr. Physiol, 3(1): 485-513.

Niendya AW, MA Djaelani, dan T Suprihatin. 2011. Rasio bobot hepartubuh mencit (Mus musculus L.) setelah pemberian Diazepam, Formalin, dan minuman beralkohol. Buletin Anatomi dan Fisiologi, 19(1).

Nunes C, A Silva, E Soares, and K Ganias. 2011. The use of hepatic and somatic indices and histological information to characterize the reproductive dynamics of atlantic Sardina pilchardus from the Portuguese Coast. Marine and Coasttal Fisheries: Dynamics, Management, and Ecosystem Science, 3: 127-144.

Ogunji J, RUAS Toor, C Schulz, and W Kloas. 2008. Growth performance, nutrient utilization of Nile Tilapia Oreochromis niloticus Fed Housefly Maggot Meal (Magmeal) Diets. Turkish Journal of Fisheries and Aquatic Sciences 8: 141-147.

Pankaj S, T Lokeshwar, B Mukesh, and B Vishnu. 2011. Review on Neem (Azadirachta indica): thousand problems one solution. International Research Journal of Pharmacy, 2(12).

Podolak I, A Galanty, and D Sobolewska. 2010. Saponins as cytotoxic agents: a review. Phytochem Rev, 9: 425-474.

Prasetiawan E, E Sabri, dan S Ilyas. 2012. Gambaran histologis hepar mencit (Mus musculus L.) strain DDW setelah pemberian ekstrak N-Heksan buah andaliman (Zanthoxylum acanthopodium DC.) selama masa pra implantasi dan pasca implantasi. Saintia Biologi, 1(1).

Sa'diyah NA, KI Purwani, dan L Wijayawati. 2013. Pengaruh ekstrak daun bintaro (Cerbera odollam) terhadap perkembangan ulat grayak (Spodoptera litura F.). Jurnal Sains dan Seni Pomits, 2(2): E111-E115.

Setyowati WAE, SRD Ariani, Ashadi, B Mulyani, dan A Hidayat. 2015. Aktivitas antifertilitas kontrasepsi dari 
kulit durian (Durio zibethinus Murr) varietas Petruk. Seminar Nasional Kimia dan Pendidikan Kimia VII. Program Studi Pendidikan Kimia Jurusan FMIPA FKIP UNS, Surakarta.

Singh, V and D Chauhan. 2014. Phytochemical evaluation of aqueous and ethanolic extract of neem leaves (Azadirachta indica). Indo American Journal of Pharmaceutical Research, 14(12): 5943-5948.

Sitasiwi AJ. 2018. Bobot badan mencit (Mus musculus L.) setelah pemberian ekstrak ethanol daun nimba (Azadirachta indica) secara oral selama 21 hari. Buletin Anatomi dan Fisiologi, 3(1): 133-139.

Smith ME and DG Morton. 2010. The digestive system: basic science and clinical conditions, $2^{\text {nd }}$ edition. China: Elsevier Limited.
Soni H, K Mishra, S Sharma and AK Singhai. 2012. Characterization of azadirachtin from ethanolic extract of leaves of Azadirachta indica. Journal of Pharmacy Research, 5(1): 199-201. Suhendro, AAAN Susraini, H Saputra, dan NP Sriwidyani. 2018. Oral administration of neem (Azadirachta indica A. Juss) leaf extract increase Cyclin D1 expression in hepatocyte regeneration in AcetaminophenIndued Hepatotoxic wistar rats. Bali Medical Journal, 7(1): 12-16.

Tatukude P, L Loho, dan P Lintong. 2014. Gambaran histopatologi hati mencit Swiss yang diberi air rebusan sarang semut (Mymercodia pendans) paska induksi dengan Carbon Tetrachlorida (CCl4). Jurnal s-Biomedik, 2(2): 459466.

Zachary JF and MD McGavin. 2012. Pathologic basic of veterinary disease, $5^{\text {th }}$ Edition. Missouri: Elsevier Mosby. 
Tabel 1. Rerata bobot badan, bobot hepar, hepatosomatik indeks, diameter hepatosit, konsumsi pakan dan konsumsi air minum mencit betina setelah paparan ekstrak etanol daun mimba selama 21 hari

\begin{tabular}{|c|c|c|c|c|}
\hline \multirow[b]{2}{*}{ Variabel Penelitian } & \multicolumn{4}{|c|}{ Perlakuan } \\
\hline & $\begin{array}{c}\mathrm{K} \\
\overline{\mathrm{X}} \pm \mathrm{SD}\end{array}$ & $\begin{array}{c}\mathrm{P} 1 \\
\overline{\mathrm{X}} \pm \mathrm{SD}\end{array}$ & $\begin{array}{c}\mathrm{P} 2 \\
\overline{\mathrm{X}} \pm \mathrm{SD}\end{array}$ & $\begin{array}{c}\mathrm{P} 3 \\
\overline{\mathrm{X}} \pm \mathrm{SD}\end{array}$ \\
\hline Bobot Badan (gr) & $25,80 \pm 1,10^{\mathrm{a}}$ & $26,54 \pm 4,01^{\mathrm{a}}$ & $26,52 \pm 3,12^{\mathrm{a}}$ & $26,22 \pm 1,35^{\mathrm{a}}$ \\
\hline Bobot Hepar (gr) & $1,40 \pm 0,10^{\mathrm{a}}$ & $1,51 \pm 0,23^{\mathrm{a}}$ & $1,43 \pm 0,31^{\mathrm{a}}$ & $1,37 \pm 0,13^{\mathrm{a}}$ \\
\hline Hepatosomatik Indeks (\%) & $5,44 \pm 0,52^{\mathrm{a}}$ & $5,69 \pm 0,22^{\mathrm{a}}$ & $5,42 \pm 1,13^{\mathrm{a}}$ & $5,22 \pm 0,56^{\mathrm{a}}$ \\
\hline Diameter Hepatosit $(\mu \mathrm{m})$ & $14,34 \pm 2,22^{\mathrm{a}}$ & $12,16 \pm 1,01^{\mathrm{a}}$ & $12,06 \pm 1.05^{\mathrm{a}}$ & $12,40 \pm 0,66^{\mathrm{a}}$ \\
\hline $\begin{array}{l}\text { Konsumsi Pakan } \\
\text { (gram/ekor/hari) }\end{array}$ & $4,82 \pm 0,64^{\mathrm{a}}$ & $3,64 \pm 0,35^{\mathrm{a}}$ & $3,58 \pm 0,74^{\mathrm{a}}$ & $3,96 \pm 0,07^{\mathrm{a}}$ \\
\hline $\begin{array}{l}\text { Konsumsi Air Minum } \\
\text { (mL/ekor/hari) }\end{array}$ & $6,38 \pm 0,73^{a}$ & $5,48 \pm 0,57^{\mathrm{a}}$ & $4,99 \pm 0,33^{\mathrm{a}}$ & $5,56 \pm 0,15^{\mathrm{a}}$ \\
\hline
\end{tabular}

Keterangan: Data disajikan berupa rataan $(\overline{\mathrm{X}}) \pm$ standar deviasi (SD). Rerata yang diikuti superskrip yang sama pada baris yang sama menunjukkan perbedaan tidak bermakna dengan uji ANOVA pada taraf kepercayaan 95\%. K : kelompok kontrol dengan akuades, $\mathrm{P} 1$ : kelompok perlakuan bahan uji dosis $8,4 \mathrm{mg} / \mathrm{kgBB}, \mathrm{P} 2$ : kelompok perlakuan bahan uji dosis 11,2 mg/kgBB, $\mathrm{P} 3$ : kelompok perlakuan bahan uji $14 \mathrm{mg} / \mathrm{kgBB}$.

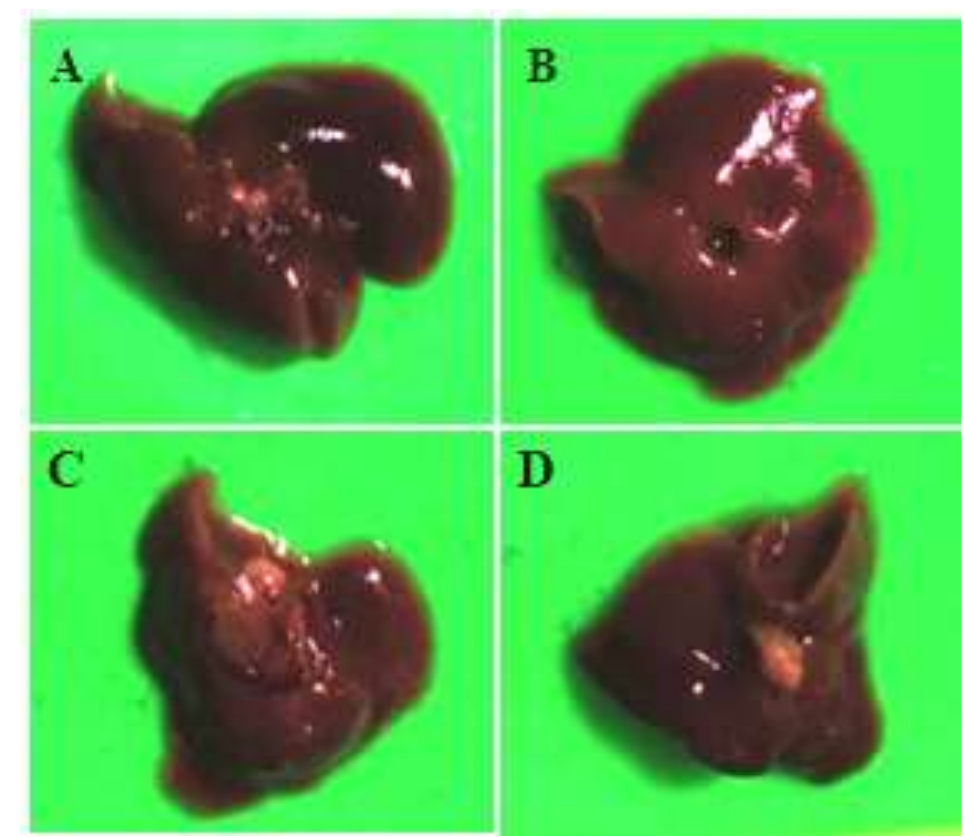

Gambar 1. Morfologi hepar semua kelompok perlakuan

Keterangan: (A) K (akuades), (B) P1 (ekstrak etanol daun mimba dosis 8,4 mg/ kg BB), (C) P2 (ekstrak etanol daun mimba dosis $11,2 \mathrm{mg} / \mathrm{kg} \mathrm{BB}$ ), (D) P3 (ekstrak etanol daun mimba dosis $14 \mathrm{mg} / \mathrm{kgBB}$. 
Hasana Anisa Nurul, dkk. Hepatosomatik Indeks dan Diameter Hepatosit Mencit (Mus musculus L.) Betina Setelah Paparan Ekstrak Etanol Daun Mimba (Azadirachta indica Juss.)
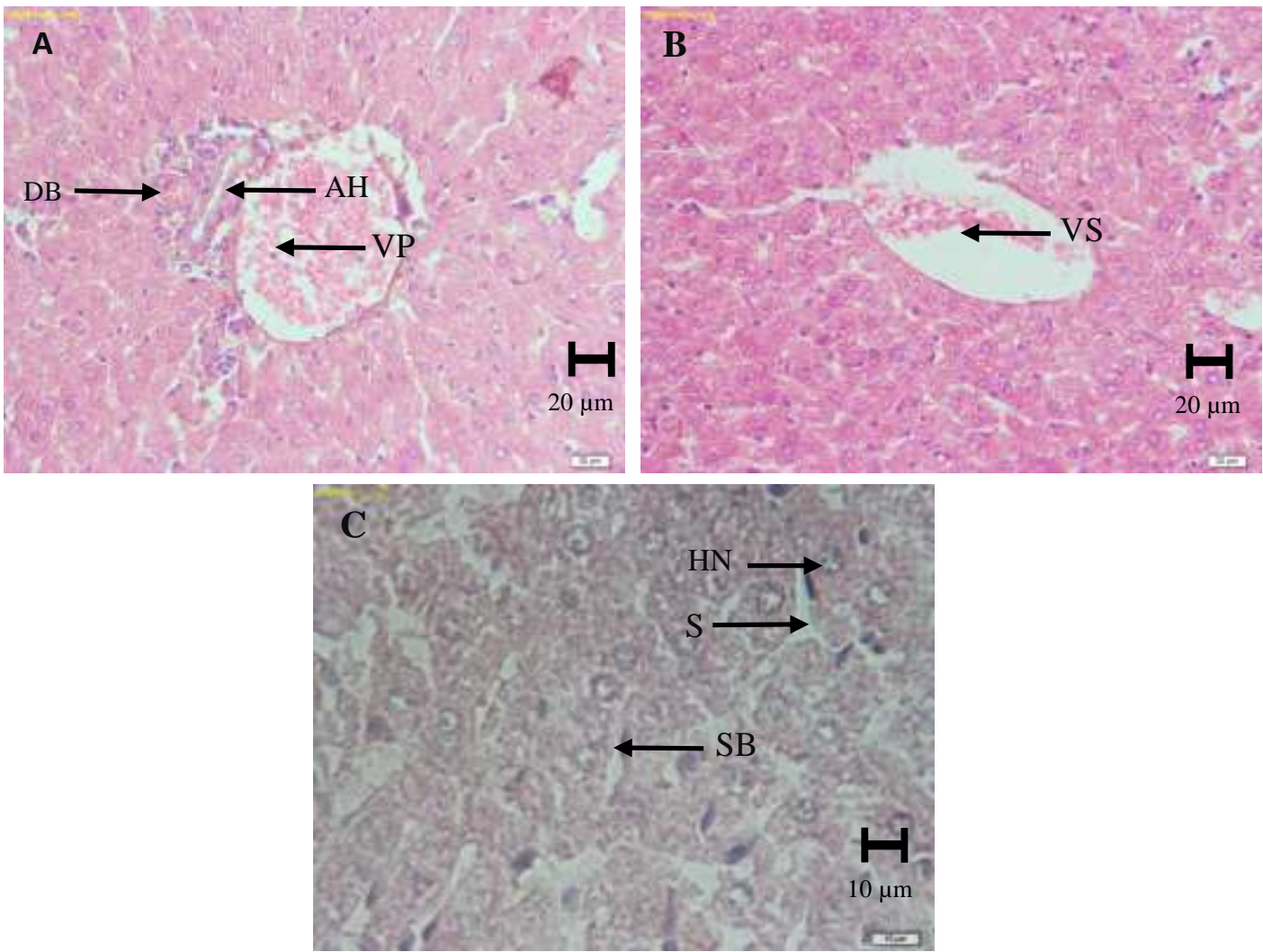

Gambar 2. Gambaran histologis hepar kelompok kontrol dengan pewarnaan HE. (A dan B) Perbesaran 400X, (C) Perbesaran 1000X.

Keterangan: (VP) vena porta, (AH) arteri hepatika, (DB) duktus biliaris (VS) vena sentralis, (HN) hepatosit normal, (S) sinusoid, (SB) sel binukleat
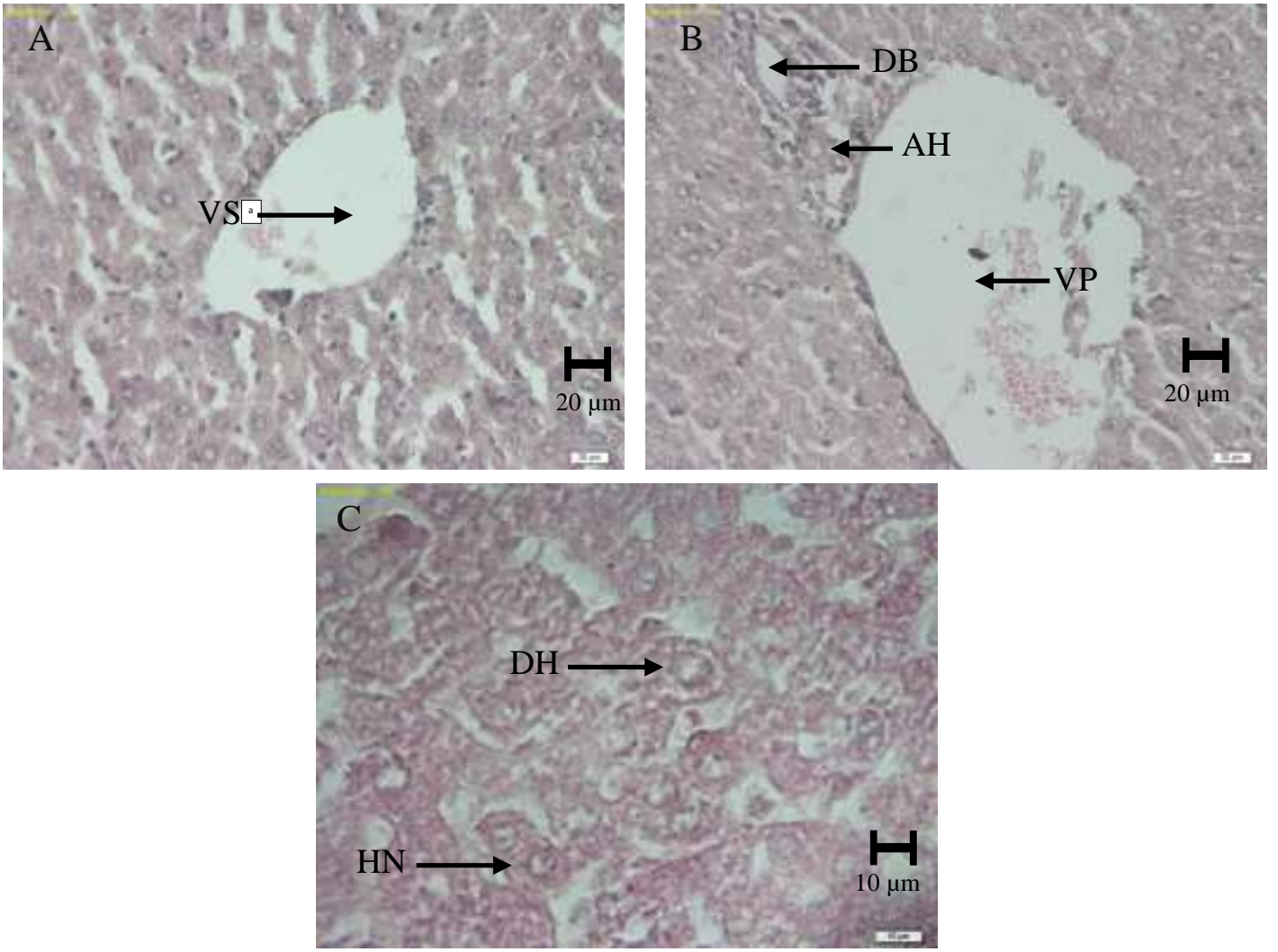

Gambar 3. Gambaran histologis hepar kelompok perlakuan P1 dengan pewarnaan HE. (A dan B) Perbesaran 400X, (C) Perbesaran 1000X.

Keterangan: (VS) vena sentralis, (VP) vena porta, (AH) arteri hepatica, (DB) duktus biliaris, (HN) hepatosit normal, (DH) degenerasi hidrofik 

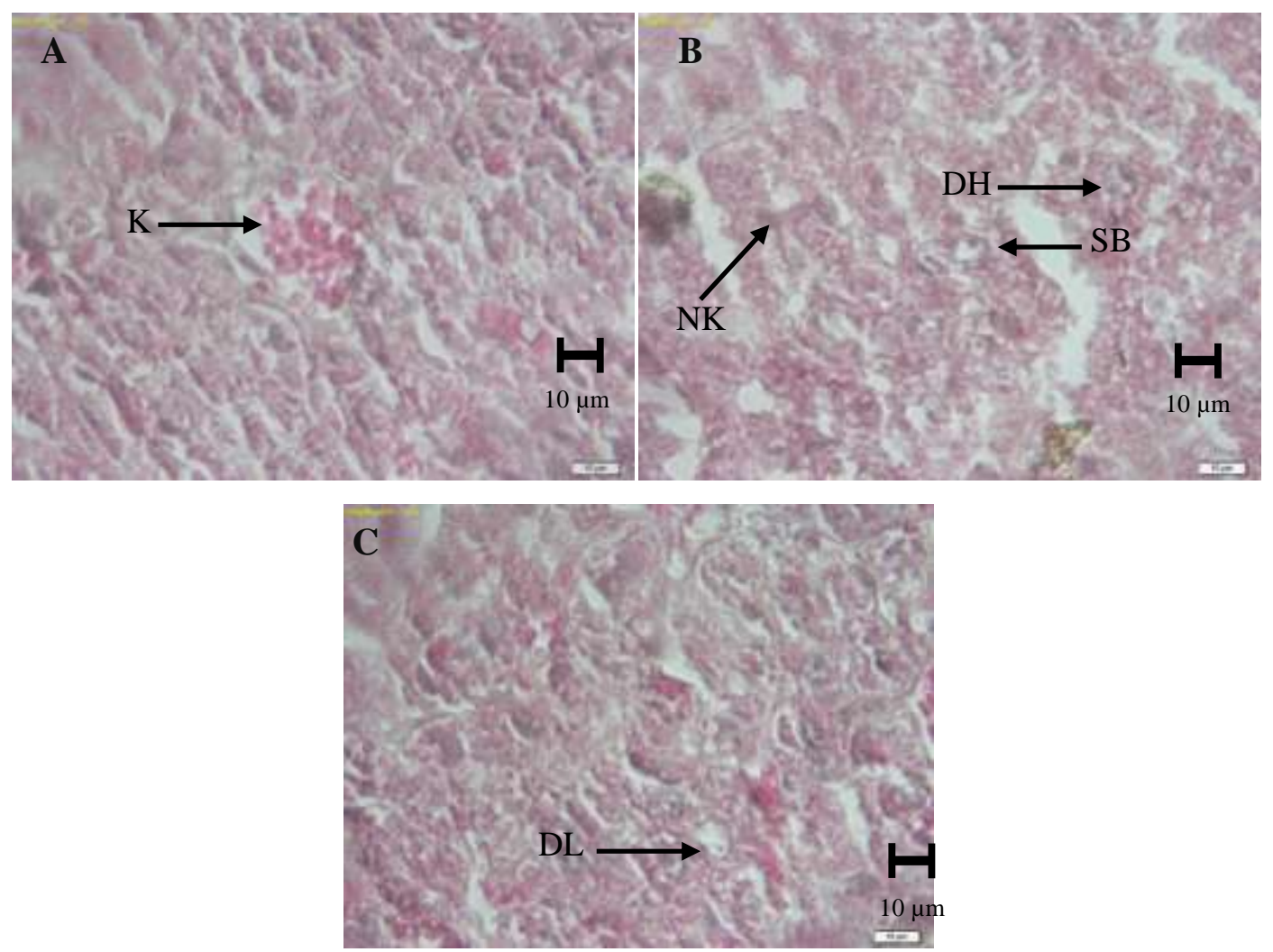

Gambar 4. Gambaran histologis hepar kelompok perlakuan P2 dengan pewarnaan HE. (A, B dan C) Perbesaran 1000x.

Keterangan: (K) kongesti, (DH) degenerasi hidrofik, (DL) degenerasi lemak, (SB) sel binukleat, (N) nekrosis
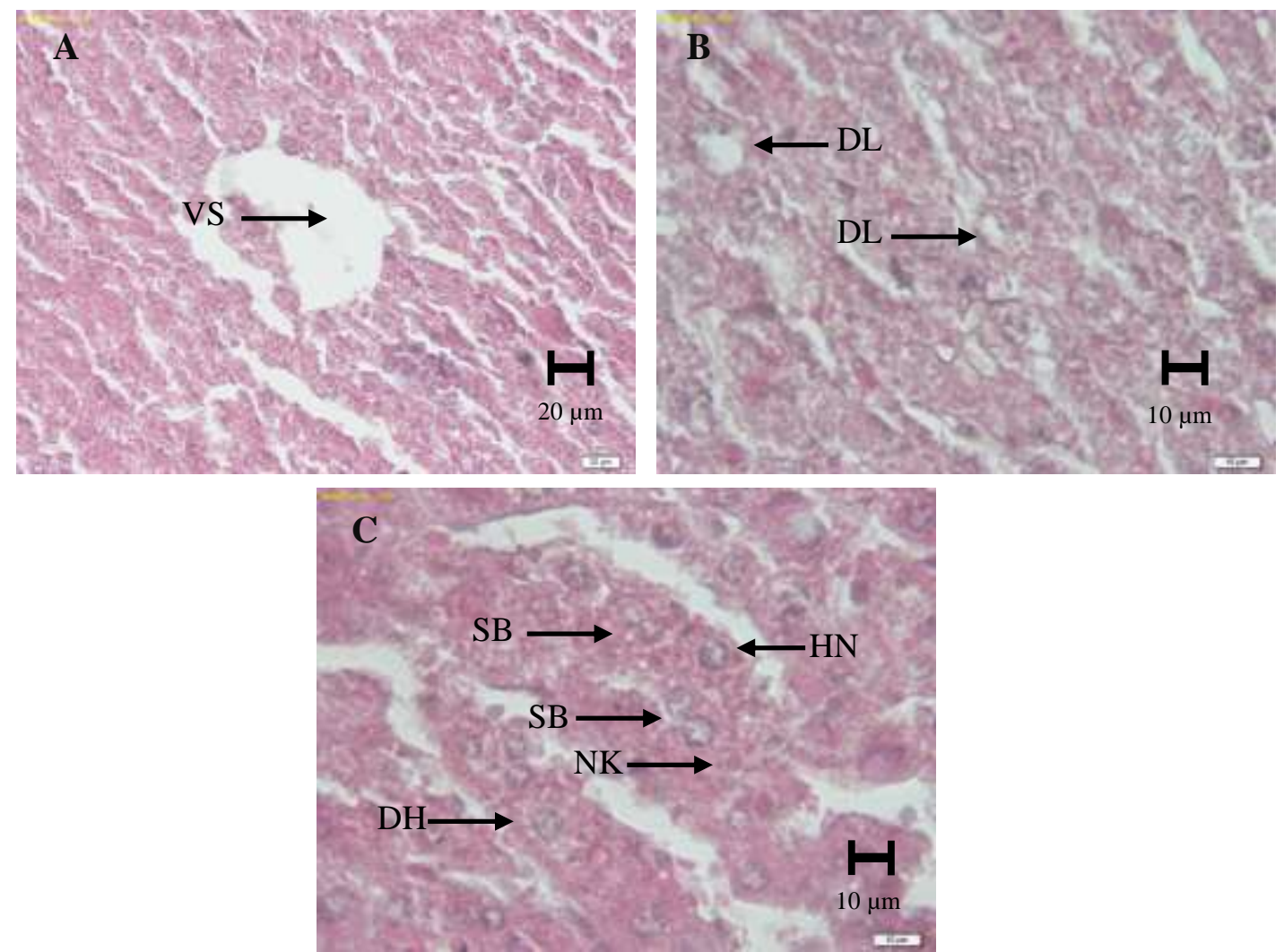

Gambar 5. Gambaran histologis hepar kelompok perlakuan P3 dengan pewarnaan HE. (A) Perbesaran 400X, (B dan C) Perbesaran 1000X.

Keterangan: (VS) vena sentralis, (DH) degenerasi hidrofik, (DL) degenerasi lemak, (N) nekrosis, (SB) sel binukleat 